\title{
Literature Review of Cultural Tourism
}

\author{
MA YAN WEI
}

Faculty of Accountancy \& Management, Universiti Tunku Abdul Rahman, Malaysia

DR.ONG SENG FOOK

Faculty of Accountancy \& Management, Universiti Tunku Abdul Rahman, Malaysia

DR. KEVIN LOW

Faculty of Accountancy \& Management, Universiti Tunku Abdul Rahman, Malaysia

\begin{abstract}
There is a long history about the academic development of cultural tourism. Study on cultural tourism has accumulated many years with rich achievements, from the definition of the concept, and also expand to other areas which relates to the research field of cultural tourism subjects is from the early anthropology to extend to the communication science, behavioral science, literature, urban studies, marketing, ecology etc.. The research purpose of cultural tourism is to promote the region development. The research of this area is worth to be paid more attention. During the research processing, more and more scholars pay attention to the method improvement which are starting from the qualitative analysis to quantitative analysis.

KEYWORD: Cultural Tourism; Region Development; Research Methodology; Literature Review
\end{abstract}

\section{INTRODUCTION}

There is a long history about the academic development of cultural tourism. Study on cultural tourism has accumulated many years with rich achievements, and which relates to the research field of cultural tourism subjects is from the early anthropology to extend to the communication science, behavioral science, literature, urban studies, marketing, ecology etc.. Study on cultural tourism also extends from the heritage tourism to deepen rural tourism, community tourism, art tourism, music tourism, sports tourism, family tourism, movie and TV tourism, wine tourism and the other special field tourism. The academic achievements are in the Tourist studies, Critique of Anthropology, Space and Culture, Journal of Travel Research, Journal of social Archaeology, Urban Studies, Cultural Geographies, Journal of Vacation Marketing, and other academic journals.

\section{DEFINITION OF CULTURAL TOURISM}

In Nineteen eights, European tourism became more and more mature, also cultural tourism developed rapidly. Italy has implemented national cultural economy strategy since 1985; cultural tourism has been developing vigorously. Cultural tourism economy as main part, compound industry with culture and tourism has become an important part of national economy.
Cohen (1979) used the two concepts of "centre" and "outside centre" to explain the motivation of cultural tourism. He pointed out, in the modern society, the love life of the tourists are often with high tension in the face of daily affairs consciousness, they want to leave the daily life to experience the culture of the interpretation for the meaning of life, which include the pursuit of personal happiness, and escaping the boring life, looking for a different way of life, obtaining aesthetic enjoyment, and contacting with other different culture. Lee \& Cromption (1992) believed that people often seek exciting and amazing experience in the travel, and get various intangible cultural experience in the cultural tourism. Robert A. Stebbin (1996) believed, Cultural tourism is activities based on the cultural motivation of tourists to pursuit "formal leisure", or "literary interests". Compared with mass tourism, attraction of attracting the cultural tourists is without broadly foundation in the public at the social level and mental level, due to which needs the tourists own certain culture quality (for example, art, cuisine, music and Architecture etc.), to obtain some knowledge (such as foreign language, history knowledge) or have some special social skills (for example, how to communicate with the locals). Stebbins(1992) pointed cultural tourism as a formal leisure activities, compared with mass tourism of the form of random leisure, which existed many differences, the most important of which is to meet the special social status and cultural interests. 
Reizinger (1994) pointed cultural tourism is to seek and deeply participate in new forms of experiencing tourism of the aesthetic, intellectual, emotional and psychological experience. Richards (1996) believed cultural tourism included a tour of historic buildings and sites, museum, art gallery, also included a visit of the contemporary painting and sculpture or watching performance art etc.. Ted Silberberg (1995) defined the cultural tourism that is tourism activities due to part or all for interested in history, art, science or destination community cultural heritage and way of life. Craik believed cultural tourism is defined that by the habit of travel, to allow tourists to enter into other cultures and other places to understand the local people, their way of life, the heritage and the arts; in a direct way to truly understand these culture and their performance in the context of history. Gilbert \& Lizotte (1998) believed cultural tourism is an emerging development of the important market which is superior to other forms of tourism activities.

In order to get a more detailed understanding of the market of cultural tourism, cultural tourism research is necessary to extend to a broader extent, which should include the study of cultural entertainment. Hughes, Allen and Wasik (2003) found in the research, innovation of the performing arts and new cultural works will be inhibited because of a lack of attractive to tourists.

Hall and Weiler (1992) believed that the cultural tourists obtained value including self realization, self improvement, self expression, self satisfaction and self promotion. Urry (1994) pointed, self promotion and self expression are the key value of the tourists.

Cros.H'sbook-- Cultural Tourism: the Partnership between Tourism and Cultural Heritage Management, the book defined depth, features, system cultural tourism and cultural tourists which had important inspiration and reference to the research. In the book, cultural tourism involves four elements of tourism (joyful); the use of cultural heritage assets (mainly construction materials); product consumption and experience (experiencing culture), tourists (tourists to experience the depth of cultural tourism).

\section{CULTURAL TOURISM AND REGIONAL DEVELOPMENT}

Ted Silberberg (1995) studied that cultural tourism brought business opportunities to museums, cultural heritage and tourism destination. Anthony J. Tighe (1995) pointed Culture and Art Festival has a greater economic value which was worthy to promotion in foreign countries. Silberberg (1995) confirmed that evaluating cultural tourism products attraction in the eight aspects: product quality, the degree of awareness, tourist service, sustainability, product unique degree, convenience, community support and degree of participation and management capability. Greg Richards (1996) studied European cultural tourism products and consumption of multinational and found that the expense of cultural tourism products and cultural tourism increased fast. Although the increase of income and improvement of education level, the demand of cultural tourism is more obvious, it was still need to guide demand.

H.Kim, C.k.Cheng \& J. Leary (2006) studied on travel patterns and trends of cultural tourist. Cultural tourism attraction is divided into four major types which are festivals and music type, the commercialization of the theme park, the local festivals and exhibitions and scenic spots with function of knowledge of education and the aesthetic. Research showed that cultural tourists travelling mode was not only determined by the number of travel times and distance, and also determined by social economy and the statistical characteristics of population. The influence of these characteristics on the cultural tourism mode is differences because of characteristics and cultural attractions.

A.P.Russo \& J.Borg (2002) put forward to the concept of friendly degree on the tourist which included urban tourism product quality, accessibility, image and other major aspects that for the purpose of assessment of cultural tourism urban competitiveness. The factors evaluation of cultural tourism urban competitiveness included tourism management strategy in the government level; reception capacity and convenience of accessing to information; services; internal and external accessibility; cultural tourism scenic spots and cultural events. They also thought that museums and cultural attractions were not enough of cultural tourism in the tourism destination, cultural tourism must develop comprehensive cultural tourism products with new technology and other means, at the same time, the cultural tourism products should be more emphasis on creativity, innovation and human communication.

M.I.Garcia, Y.Fernandez \& J. L. Zofio (2003) studied economic contribution degree of Spanish culture and leisure industry from the three levels of nation, department and region. They believed that the Spanish cultural sector created economic value. Performance art, music art, audio-visual art (mainly spread by television) and publication, printing products accounted for the entire economic value added $70 \%$.

A.P. Russo \& J. Borg (2002) studied the problems of cultural tourism planning and cultural tourism sustainable development by the case of European cities. They believed that cultural tourism resources will not dry up. But if the sustainable development of cultural tourism conditions were not 
guaranteed, so for decades huge investment in cultural tourism will be in vain.

Garrod \& Fyall (2000), Leslie \& David (2005) pointed that cultural tourism planning often ignored the problems including communication with the public, destination and cultural attractions accessibility and soft environment etc.. Fossati \& Panella (2000) pointed tourists willingness were not subject to the destination the capacity constraints, therefore, the tourist may not be satisfied with the products and services of cultural tourist attractions (beyond the destination reception capacity), thereby reduced the degree of satisfaction of tourists to the tourism destination.

\section{CULTURAL TOURISM RESEARCH METHOD}

Cultural tourism research method consists qualitative and quantitative analysis also includes case studies and theoretical research. G.Richards \& W.Munsters (2010) edited a book-- Cultural Tourism Research Methods which expounded the process of method development which is from the time list that in the 1980s cultural tourism research tended towards quantitative work, often in the form of participant surveys submitted to statistical analysis. In the early 1990s the discovery of cultural heritage as an economic development tool stimulated many quantitative studies of visitors to heritage sites, again usually based on surveys. As the 1990s progressed, however, cultural tourism studies became more and more based on qualitative methodology, as research shifted to the social and cultural aspects of cultural tourism production and consumption. And then, much of this research has been conducted through in-depth interviews with tourists and cultural producers, and increasingly through content analysis of written documents and digital media relating to such features (brochures, websites, etc.). This book carried on the summary of the cultural tourism method through studies the literature on the research method about cultural tourism, mainly introduces respectively the qualitative and quantitative analysis, and the comparison of the qualitative and quantitative analysis, mixed qualitative-quantitative approaches, interdisciplinary approaches.

In recent years, the methods focus on using the model to analysis which includes theoretical model and econometric model. John Imbal (2010) introduced and explained various theoretical models of cultural tourism which are A simple model of culture tourism; A multi-concept model of culture tourism; A stakeholder-relationship model of culture tourism; An activity based model of culture tourism; An outcome model of culture tourism; A variable commercialization model of culture tourism; A distribution model of culture tourism; A destination planning and communication model of culture tourism.

The method of quantitative analysis using the technology of statistical analysis is to collect and analyze the data which are reflected by objective things, in order to more clearly describe the variation rule of data; meanwhile study causal relationship of objective things, and process regression analysis among variables, to grasp the intrinsic variation between variables. The quantitative analysis is the tendency of academic development which will better study cultural tourism into applied management. There are some literatures in recent years were used by quantitative analysis. José G. Vargas-Hernández (2012) used a normative model to determine the potential of cultural tourism. Tatiana Abankina (2013) introduced findings of comparative analysis and various models based on cultural heritage resources to foster regional development. M.S.Rivero \& J.Fernández (2012) used a latent model approach to get the conclusion that the empirical results indeed confirmed that the strong cultural inclination of these tourists is reacted in a differential valuation relative to the rest of the tourists with respect to the attributes of the image of these towns. Delores M. Frias (2012) used a multicultural sample of 371 tourists from variety countries of Europe to prove their points that culture influences information source on a destination's image amongst tourists.

\section{CONCLUSION}

According to the OECD (2009), cultural tourism accounted for around $40 \%$ of all international tourism, or 360 million arrivals in 2007. Cultural tourism is worth to depth research. In summary, research on cultural tourism presents the development stage from prosperity to deepen, refined the whole research process, cultural studies point to the strong sociology and culture atmosphere, cultural tourism economic value and social cultural value will be the organic integration. Commodity and commercial of cultural tourism has been more monitoring and alert, cultural tourism with cultural industry research will be more linked together.

\section{REFERENCES}

[1] Delores M. Frias (2012) The Formation of a Tourist Destination's Image via Information Sources: the Moderating Effect of Culture. INTERNATIONAL JOURNAL OF TOURISM RESEARCH. Int. J. Tourism Res. 14, 437-450 (2012)

[2] Greg Richards \& Wil Munsters (2010). Cultural Tourism Research Methods. CABI Publishing.

[3] José G. Vargas-Hernández. (2012) A NORMATIVE MODEL FOR SUSTAINABLE CULTURAL AND 
HERITAGE TOURISM IN REGIONAL DEVELOPMENT OF SOUTHERN JALISCO. INNOVATIVE JOURNAL OF BUSINESS AND MANAGEMENT. Vol 1: 1 (2012) 5 15.

[4] John Imbal.(2011). Models for studying culture tourism. DWU Research Journal Volume 15, November 2011

[5] Marcelino Sánchez Rivero \& Juan Ignacio Pulido Fernández (2012). Testing Heterogeneous Image in
Cultural/Non - cultural Tourism Markets: a Latent Model Approach. INTERNATIONAL JOURNAL OF TOURISM RESEARCH. Int. J. Tourism Res. 14, 250-268 (2012)

[6] TATIANA ABANKINA.(2013). REGIONAL DEVELOPMENT MODELS USING CULTURAL HERITAGE RESOURCES. INTERNATIONAL JOURNAL OF CULTURE, TOURISM AND HOSPITALITY RESEARCH. VOL. 7 NO. 12013 